\title{
DOWNSTREAM CONTAMINATION OF IN-SERIES VAPOURIZERS
}

\author{
R.E. WICKETT, M.D., L.C. JENKINS, B.A., M.D., C.M., F.R.C.P.(C), AND \\ L.S. RooT ${ }^{*}$
}

\section{INTRODUCTION}

RECENTLY, there have been reports of contamination of in-series vapourizers by transfilling. ${ }^{1,2}$ Murray and associates have shown that if a vapourizer designed to volatilize a low vapour-pressure liquid (methoxyflurane) is placed in a downstream series position relative to a high vapour-pressure vapourizer (halothane) the methoxyflurane vapourizer containing even small amounts of halothane can deliver anaesthetic concentrations of this agent in addition to the expected methoxyflurane output.

This transfilling most likely occurs when vapourizers in series are accidentally or purposefully opened simultaneously.

To try to determine the extent of this problem of downstream contamination a spot check was run on 20 anaesthetic machines in our department with methoxyflurane vapourizers downstream from halothane vapourizers.

\section{Methods}

1. Each anaesthetic machine was tested for halothane output with the halothane vapourizer off but with the methoxyflurane vapourizer on at 0.5 per cent with a flow of $5 \mathrm{l} / \mathrm{min}$ of oxygen.

2. The sampling site was the port for the open circuit, to eliminate contamination from rubber circuitry or carbon dioxide absorber.

3. To be sure that the halothane was coming from the methoxyflurane vapourizer and not from a leaking halothane vapourizer dial, the halothane levels were tested in the same manner with both vapourizers off and oxygen only running at $5 \mathrm{l} / \mathrm{min}$.

4. Determinations of halothane concentrations were carried out by gas chromatography ( see Appendix 1).

\section{REsults}

The results are displayed in Table I. The halothane concentrations are reported in parts per million (P.P.M.). It can be seen that practically all of the methoxyflurane vapourizers were putting out measurable amounts of halothane ranging from one p.p.m. to 1400 p.p.m. ( 0.14 per cent).

-Department of Anaesthesia, Vancouver General Hospital and Faculty of Medicine, University of British Columbia.

Canad. Anaesth. Soc. J., vol. 21, no. 1, January 1974 
TABLE I*

Downstream Contamination

\begin{tabular}{ccc}
\hline \hline $\begin{array}{c}\text { P.P.M. Halothane } \\
\text { Machthetic } \\
\text { Machine \# }\end{array}$ & $\begin{array}{c}\text { With 0.5\% MOF On } \\
\text { Halothane Vapourizer Off }\end{array}$ & $\begin{array}{c}\text { P.P.M. Halothane } \\
\text { With Oxygen Only On }\end{array}$ \\
\hline 1 & 5.5 & 0 \\
2 & 44.0 & 1.0 \\
3 & 1400.0 & 0 \\
4 & 3.2 & 0.5 \\
5 & 218.0 & Trace† \\
6 & 35 & Trace \\
7 & 61 & 0 \\
8 & 3.5 & Trace \\
9 & 0.5 & 0 \\
10 & 25 & Trace \\
11 & 8.0 & 1 \\
12 & 0 & 0 \\
13 & 11 & 2 \\
14 & 50 & 0.5 \\
15 & 8.0 & 0 \\
16 & 30.0 & 2.0 \\
17 & 8.5 & 0.5 \\
18 & 1.0 & Trace \\
19 & 1200 & 0 \\
20 & 2.5 & Trace \\
\hline
\end{tabular}

*Sampling site was port for open circuit.

†Trace being less than $1 / 4$ of 1 P.P.M.

\section{Discussion}

These results indicate that contamination had occurred in almost all the downstream vapourizers. There was no detectable contamination in \#12 and it was questionable in numbers $4,9,18$ and 20 . This indicates that 70 per cent of the vapourizers tested had some downstream contamination. In general the halothane concentrations were low but in two (nos. 3 and 19) the levels were significantly high, being 1400 p.p.m. ( 0.14 per cent) and 1200 p.p.m. (0.12 per cent) respectively.

Whether the contamination occurred from both vapourizers being open together or from a slow leak of halothane into the methoxyflurane vapourizer is not known.

These results suggest that small concentrations of halothane may be delivered to the patient from anaesthetic circuits even if the halothane vapourizer is off and an open circuit is used.

These small concentrations of halothane become important in the light of concentration dependence of hepatic halothane metabolism ${ }^{3}$ and the possibility of "halothane hepatitis" being produced on a hypersensitivity basis.

It is suggested that vapourizers not be placed in series on anaesthetic machines, but have completely separate circuits.

\section{SUMMARY}

Contamination of in-series vapourizers by transfilling has been reported ${ }^{1,2}$ and it has been shown that if a vapourizer designed to volatilize a liquid of low vapour 
pressure (methoxyflurane) is placed in a downstream series position relative to a vapourizer designed for a liquid of high vapour pressure (halothane), the methoxyflurane vapourizer containing even small amounts of halothane can deliver anaesthetic concentrations of this agent in addition to the expected methoxyflurane output. This transfilling most probably occurs when vapourizers in series are opened simultaneously.

To determine the extent of this problem halothane concentrations were measured in the output from methoxyflurane vapourizers which were downstream from halothane vapourizers on twenty anaesthetic machines. The results are displayed in Table I. These results indicate that contamination had occurred in 70 per cent of the vapourizers tested and that in two of the twenty machines the concentrations were significantly high ( 1400 p.p.m. and 1200 p.p.m.).

It is suggested that vapourizers not be placed in series on anaesthetic machines, but have completely separate circuits.

\section{ACKNOWLEDGMENTS}

This study is partially funded through grants from the British Columbia Research Foundation and The British Columbia Medical Services Foundation.

\section{REFERENCES}

1. Muraay, W.J., Zsigmond, E.K., \& Fleming, P. Contamination of in-series vaporizers with halothane-methoxyflurane. Anesthesiology 30: 5, 487-490 (May) (1973).

2. Dorsch, S.E. \& Donsch, J.A. Cross contamination between vaporizers in series. Abstracts of scientific papers, Annual Meeting, A.S.A., 161-162 (1971).

3. Sawyer, D.C., Eger, E.I., Gahlman, S.H., Cullen, B.F., \& Impelman, D. Concentration dependence of hepatic halothane metabolism. Anesth. 34: 230 (1971).

\section{APpendix I}

\section{Gas Chromatography Details}

Gas Chromatograph Type: Varian ${ }^{\circledR}$ aerograph 2740 with F.I.D.

Columns: $6^{\prime} \times 18^{\prime \prime}$ S.S. 3 per cent S.E. 30 with 100-120 mesh varaport.

Temperatures: Injection port $80^{\circ} \mathrm{C}$.

Column oven $50^{\circ} \mathrm{C}$.

Detector $150^{\circ} \mathrm{C}$.

Flow Rate: $\mathrm{N}_{2} 26 \mathrm{ml} / \mathrm{min}$.

$\mathrm{H}_{2} \quad 30 \mathrm{ml} / \mathrm{min}$

Air $300 \mathrm{ml} / \mathrm{min}$.

Retention Time for Halothane: 34 seconds.

Standards prepared by Serial Dilution. 